\title{
CAMPOS DE DEMÉTER: DA IMPOSSIBILIDADE DE SEPARAR A CiênCIA, A ÉTICA E A ESTÉTICA NA HERMENÊUTiCa dA PAisagem
}

\author{
António Queirós \\ (Centro de Filosofia da Universidade de Lisboa)
}

\section{Paradigma e mudança. Repensar a paisagem}

A definição geral de paradigma compreende "uma matriz disciplinar", uma constelação de crenças, valores e técnicas compartilhados por uma comunidade ${ }^{1}$. A presença de algumas anomalias não é bastante para abandonar o paradigma precedente. Isto acontece somente quando, no âmbito do estudo fenomenológico, se podem observar múltiplos eventos inexplicáveis ou inesperados e quando um paradigma rival emerge. Tal não acontece de repente.

O paradigma permanece estável quando pode aumentar a exatidão de suas observações e avaliações; e ser ampliado para estudar fenómenos novos; e determinar os valores de constantes universais; continua a ser competente para formular as leis quantitativas que permitem uma compreensão melhor dos enlaces entre os diferentes fenómenos; e alimenta a sua capacidade de criar processos novos para aplicar o paradigma em áreas novas. Mas o reconhecimento da existência de dois paradigmas em competição necessita que os seus investigadores usem a mesma estrutura conceptual, o que, nas áreas da filosofia e da paisagem, não é fácil, porque há uma grande diversidade de conceitos aplicados ao mesmo tipo de fenómenos.

Perante a dificuldade de conceptualizar e universalizar a linguagem científica e académica, neste artigo usaremos as duas rotas metodológicas apontadas por Lakatos, uma heurística negativa, que nos indica os cami-

\footnotetext{
${ }^{1}$ Kuhn, T. S., The Structure of Scientific Revolutions, University of Chicago Press, Chicago, 1962.
} 
nhos de pesquisa a evitar e uma heurística positiva, que nos remete para as proposições científicas "não falsificáveis" a desenvolver².

\section{Natureza e ambiente}

$\mathrm{Na}$ linguagem comum, tal como na literatura académica não-filosófica, os dois conceitos, de natureza e de ambiente, são usados como sinónimos ou equivalentes. Aplicados ao destino turístico e à paisagem, sobretudo à paisagem das regiões rurais, esta é geralmente classificada como "paisagem natural". Ora, a filosofia moderna, em particular a Filosofia da Natureza e do Ambiente, distingue o conceito de natureza do conceito de ambiente. Usaremos nesta reflexão a nossa própria visão do problema e iremos propor a convergência das diversas cosmovisões filosóficas e científicas para enfrentar as suas aporias.

Na perspetiva da cosmovisão da Filosofia da Natureza e do Ambiente, o ser humano, separado culturalmente da Natureza e das distintas culturas humanas pelas conceções antropocêntricas e etnocêntricas, tem não só uma comum origem e pertença à mesma e única família Humana, como está ecologicamente ligado ao ambiente biológico, geológico e cosmológico de todos os seres e coisas. Esta reintegração do Homem na Natureza, sem nenhum estatuto de domínio ou privilégio, conduz ao reconhecimento do atributo de "complexidade" da paisagem humanizada e à reavaliação moral da interação entre a terra e o homem, simultaneamente destruidor e criador de novos biótopos.

A paisagem transformou-se num sedimento da vida e da morte de todos os seres da comunidade biótica e abiótica, no seu ciclo de nascimento e morte, reciclar e reutilizar. A expansão da espécie humana por todas as regiões do globo e a sua adaptação à diversidade dos habitats conduziu a que praticamente todas as paisagens, mesmo as mais remotas, sejam percecionadas como paisagens humanizadas, paisagens culturais transformadas pela migração da nossa espécie para todas as regiões do mundo.

Na Idade Moderna, com a expansão europeia, mas também da China no século XVI e depois, no século XIX, a divisão imperialista dos territórios coloniais, desenvolveu-se uma nova relação da Humanidade com a Natureza, universalizou-se e globalizou-se a ação antrópica: deixaram de existir os grandes quadros naturais puros, toda a paisagem se transforma, direta ou indiretamente, pela atividade humana.

${ }^{2}$ Lakatos, M., Criticism and the Growth of Knowledge, Cambridge University Press, Cambridge, 1970. 
A história política acompanha e determina a evolução das condições ambientais da paisagem. Também por isso o conceito de paisagem é mais do que "território". E no plano da política, destacaremos aqui a Conferência de Estocolmo sobre o Meio Ambiente, organizada pelas Nações Unidas em 1972, como o primeiro ato político fundador de uma consciência mundial sobre a crise do ambiente e de uma nova ética política ambiental, com profundas consequências sobre o tema da nossa reflexão.

$\mathrm{O}$ conceito de paisagem, segundo Augustin Berque, emerge na China já no século IV e na Europa com o renascimento (séc. XIV), como atitude contemplativa e estética das classes dominantes ${ }^{3}$. Arnold Berleant, ao elaborar o conceito de "paisagem sempre em transição" enfatiza a trajetória da visão pinturesca do século XIX para a experiência multissensorial contemporânea e a expansão das paisagens urbanas, e estabelece, com o seu outro conceito de Negative Aesthetics, que algumas práticas humanas na paisagem, ao ofender a nossa sensibilidade estética, assumem diretamente consequências morais ${ }^{4}$. Mas se o distanciamento estético é atributo aristocrático, tal significa que na relação entre os camponeses e a terra não exista algo mais que a luta pela sobrevivência e até uma ética camponesa? E há um saber científico que sustente as éticas ambientais?

A tese do fim da natureza é a tese da dominação e inteligibilidade completas da natureza, o "sociocentrismo" de que fala Catherine Larrère. Admitiu-se a ideia de uma natureza criada por Deus, natura naturans (é o primeiro momento da modernidade clássica), uma natureza-processo e depois uma natureza-objeto, natura naturata, natureza artefacto, exterior ao homem, de que ele se separou ao instrumentalizá-la. Mas, como se sublinha na sua obra de referência, os processos naturais continuam e a artificialização da natureza não é controlável pelo homem nos seus efei$\operatorname{tos}^{5}$. Acresce, que a filosofia ambiental reintegrou o homem na natureza, sem nenhum estatuto de domínio ou privilégio. Mas reconheceu na Vida Humana o ente mais complexo da evolução cósmica, que não o seu cume ou final. A extinção do homo sapiens sapiens e das espécies associadas à nossa evolução, um mundo imaginário de vegetais, micróbios e insetos, improvavelmente daria de novo origem à espécie humana ou mesmo aos mamíferos.

E assim, concluímos nós, o humanismo regressa ao centro da reflexão moral, mas noutra visão ética. Se enquadrarmos o surgimento dos

${ }^{3}$ Filosofia da Paisagem. Uma Antologia. Coordenação de Adriana Veríssimo Serrão, CFUL, 2012.

${ }^{4}$ Berleant, A. (2011) Changing Landscapes, Keynote lecture at "Transition Landscapes/ Paysages en Transition," International Conference, Lisbon, Portugal.

${ }^{5}$ Larrère Catherine, Larrère, Raphaël. Du Bon Usage de La Nature. Aubier, Paris, 1997. Editado para Português pelo Instituto Piaget. 
antepassados da espécie humana há 4 ou 5 milhões de anos, no quadro do tempo biológico, que é imenso, nada nos assegura que, tal como aconteceu com os dinossáurios há sessenta e cinco milhões de anos, o reino dos mamíferos não termine e outras formas de existência mais avançadas e inteligentes continuem a perpetuar a música da vida pelos espaços siderais. E ninguém pode imaginar hoje qual é o elo da cadeia onde o salto evolutivo se produzirá, como ninguém sonhou antes que o tetravô da nossa condição de quadrúmanos fosse um insignificante roedor, que sobreviveu à extinção generalizada das espécies dominantes no final da era mesozóica.

Em coerência, devemos igualmente considerar que os múltiplos laços entre todas as formas de vida (e mesmo destas com o ambiente abiótico), obrigam, para além do dever de preservação da nossa espécie, a conservar a diversidade dos seres e os seus nichos ambientais, de cujo equilíbrio (?) dinâmico, como na pirâmide trófica de Aldo Lepold, tudo depende $^{6}$. E daqui decorre o princípio da preservação da Vida, antes do Homem e da Terra com toda a sua biodiversidade.

De qualquer modo, mesmo que a reflexão filosófica sobre o significado de paisagem possa, eventualmente, dispensar a informação científica no plano do debate conceptual, já não a pode recusar no plano das éticas práticas. Tomemos como exemplo a destruição do mosaico agro-silvo-pastoril, da paisagem cultural, pelo ciclo das plantações monoespecífica (pinheiro bravo e eucalipto) - fogo - escorrências torrenciais, que acentua os efeitos erosivos das escombreiras de gravidade e os fenómenos de ravinamento. $\mathrm{O}$ solo desaparece e com ele o coberto vegetal e o abrigo faunístico de muitas espécies; no seu lugar, passeia-se agora a cobra rateira. E na terra exangue pela plantação sistemática de eucaliptos ao longo de decénios, sem água nem húmus, as "chaminés de fadas", na expressão popular, são de facto os estigmas de um "solo cadáver".

\section{A Ética da Terra}

A argumentação científica como suporte do discurso ambiental e moral, atravessa a obra de referência da Ética da Terra de Aldo Leopold, um técnico florestal e não um académico (depois de Walt Whitman, e do transcendentalismo de David Thoreau e Waldo Emerson, a John Muir e G. Pinchot, pioneiros da gestão racional da floresta e do ambiente ou George Perkins Marsh), que a retira dos estudos de Darwin e dos avanços científicos da Ecologia.

${ }^{6} \mathrm{O}$ conceito de equilíbrio da natureza está há muito sob a crítica das ciências do ambiente, incluindo a fundamentação científica desenvolvida por Leopold. Equilíbrio e caos coexistem no mesmo processo de evolução. 
O sentimento da necessidade de ajuda e defesa comum, desenvolvido ao longo do processo de seleção natural, gerou o conceito de comunidade, fundamento da ética. E é uma nova conceção da natureza que emerge, agora entendida como uma sociedade de plantas, animais, minerais, fluidos e gases, estreitamente ligados e interdependentes. Uma comunidade alargada aos entes naturais. Todas as éticas assentam sobre uma premissa - o indivíduo como membro de uma comunidade interdependente:

The land ethic simply enlarges the boundaries of the community to include soils, water, plants, and animals, or, collectively: the land. ${ }^{7}$

Nesta linha de pensamento, duas correntes emergiram em paralelo: o biocentrismo (modelador das organizações, Earth first, Greenpeace, Wilderness Society), que atribui um valor intrínseco a toda a entidade viva; e o ecocentrismo focalizado nos deveres que temos face à comunidade biótica de que fazemos parte. Quanto aos defensores da deep ecology não julgam necessário desenvolver qualquer ética ambiental. Não se trata de aplicar a novos objetos, como a natureza, as teorias morais pré-existentes. A natureza passa a estar incluída no nosso campo de reflexão moral, os nossos deveres, antes limitados aos seres humanos, passam a ser extensivos aos outros entes naturais. A Consciência Ecológica (os deveres para com a Natureza), será assim, Conservation is a state of harmony between men and land... ${ }^{8}$

The image commonly employed in conservation education is «the balance of nature» ...this figure of speech fails to describe accurately what little we know about the land mechanism. A much true image is the one employed in ecology: the biotic pyramid. ${ }^{9}$

A pirâmide biótica e abiótica, que Aldo Leopold descreve assim:

Plants absorb energy from the sun. This energy flows through a circuit called the biota, which may be represented a pyramid consisting of layers...The species of a layer are alike not in what they came from, or what they look like, but rather in what they eat...The lines of dependency for food and other services are called food chains...The pyramid is a tangle of chains so complex as to seem disorderly, yet the stability of the system proves is to be a highly organized structure. Its functioning depends of the co-operation and competition of its diverse parts. ${ }^{10}$

${ }^{7}$ Leopold, Aldo, A Sand County Almanac. New York: Oxford University Press, 1949, p. 239.

8 Ibidem, p. 243.

${ }^{9}$ Ibidem, p. 251.

10 Ibidem, pp. 251 e 252. 
Na perspetiva da cadeia biótica a classificação do homo sapiens na ordem dos Primatas, transforma os seus membros em "irmãos e primos", integra o homem na família dos hominídeos, com gorilas e chimpanzés, e aparenta-o com macacos e lémures. O solo é nesta visão científica, o suporte da Vida, nele vivem e permanecem biliões de decompositores: Termite, red velvet mite, pseudoscorpion, springtal, earthworm, root tipe, nematode, fungi, protozoa, bacteria. ${ }^{11}$

\section{A Ética Animal}

Caberia ao australiano Peter Singer e ao americano Tom Regan enfatizar os sentimentos e os direitos dos animais face à brutalidade dos processos produtivos modernos: clonagem genética, jaulas prisão, rações baseadas na carne triturada de animais mortos e saturadas de hormonas, violação sistemática dos ritmos naturais e das necessidades da vida animal, tudo isto em função do lucro máximo.

Em nome do princípio da igualdade, os dois autores referidos recusam o conceito da superioridade da espécie humana, que comparam ao racismo, por violar aquele princípio, censurando à maioria dos humanos o não reconhecimento da capacidade de sentir e sofrer dos animais. Nas suas obras afirmam que os animais são sujeitos de interesse em não sofrer e também, acrescenta Regan, são sujeitos de direito, por que são sujeitos de uma experiência de vida que possui valor intrínseco. Sobre estes fundamentos postulam o mais radical imperativo moral: a ampliação do conceito de pessoa.

Proponho o uso de «pessoa», no sentido de um ser racional e autoconsciente, para incorporar os elementos do sentido popular de «ser humano» que não são abrangidos por «membro da espécie Homo Sapiens $\gg .{ }^{12}$

Singer, postulando a obrigação ética de ajudar, vai desmontando uma a uma as objeções que se lhe opõem: cuidar de nós mesmos; deixar a cargo do governo...e a derradeira, o padrão alto da ajuda...

Na obra citada de Peter Singer pode ainda ler-se, a seguinte denúncia, no que respeita à ajuda efetiva que os países ricos do Norte se comprometeram a conceder aos países pobres do Sul: só a Suécia, a Holanda, a Noruega e alguns dos países árabes que exportam petróleo atingiram o modesto

${ }^{11}$ Illustration of the major soil biota that interact with plants (Soil Quality Information Sheet, U.S. Department of Agriculture).

12 Singer, Peter. Ética Prática, do capítulo Tirar a Vida de Animais. São Paulo: Editora Martins Fontes, 1993. pp. 98 e 99. 
objetivo estabelecido pela ONU, de $0,7 \%$ do Produto Nacional Bruto. ${ }^{13}$ Torna assim claro que há, entre a fome no mundo e a matança brutal dos animais, um padrão civilizacional comum, o da sociedade de consumo atual e do seu modo amoral e desigual de produção e circulação das mercadorias. A sua visão filosófica evoca o pensamento moral de António Vieira: "Comerem-se uns animais aos outros é voracidade e sevícia, e não estatuto da natureza." 14 Mas também o premonitório filosofema aquiliniano "A natureza não tem simpatias especiais para nenhum dos seus seres." 15

\section{Ética camponesa: Ética da Terra e da Vida e Ética Animal}

A cultura camponesa com a qual Aquilino e Torga, Ferreira de Castro e Raul Brandão, Redol ou Namora conviveram, na primeira metade deste século, conservava nas relações com a terra, os animais, a paisagem humanizada, nos costumes e no imaginário mágico e religioso, uma ética antiquíssima que a luta pela sobrevivência e o conhecimento empírico da vida moldaram contraditoriamente.

Dilemas éticos: os fojos dos lobos são armadilhas que remontam à pré-história e permitiam o extermínio sistemático das alcateias, mas as peças de caça pejadas estavam interditas aos caçadores; as grandes aves de rapina, como os grifos, verdadeiros agentes sanitários que limpavam as serranias dos cadáveres e miasmas doentios eram respeitadas, mas as mais pequenas, como os milhafres, acusados de rapinar as capoeiras, eram perseguidos nos ninhos.

A comunidade rural e a alienação urbana: a proximidade entre os vizinhos, tal como do criador e do consumidor dos animais, quando as economias de subsistência resistiam ainda ao mercado único e capitalista, conduziam à permanência de laços de solidariedade social e de afetividade com os animais, hoje totalmente estranhos ao cidadão urbano que não convive com seu parceiro de condomínio e consome a carne iconizada (hamburger-cachorro-prego-rissol etc.) de exemplares completamente desconhecidos.

Dualidades morais, Festa-Luto-Sagrado-Profano: paradigmas dessa afetividade perdida (e contraditória) são, por exemplo, a partilha social da dor da morte ou da alegria do casamento, com os rituais de velório e do funeral coletivos, ou a oferta de guloseimas aos vizinhos. São as lágrimas da mulher que criou o porco quando a matança se inicia, mesmo sabendo

13 Ibidem, p. 233.

14 Vieira, Padre António. Sermão de Sto. António aos Peixes. Sermões. Lisboa: Editores Reunidos e R.B.A. Editores, Público, 1994, p. 41.

15 Ribeiro, Aquilino. Romance da Raposa. Amadora: Livraria Bertrand, 1975. Posfácio. 
que esse sacrifício é essencial à subsistência do lar e a entrega dessa tarefa a um especialista estranho à família, chamado a executar impessoalmente o golpe fatal. São as canções de incitamento dos bois quando lavram e o corte diário de erva fresca para o "vivo" da casa... mas também o uso da vergasta e do aguilhão apenas quando já não há outro meio de conduzir o animal. Os processos de domesticação conduziram a uma ética animal empírica que a produção moderna desprezou completamente.

Ética prática, preceitos éticos e ação moral: a regra de aviar primeiro os animais domésticos e só depois servir a ceia. A prática de criar os animais em territórios amplos, permitindo-lhes utilizar o espaço segundo as suas necessidades e ritmos biológicos, alimentares, de acasalamento e de pisoteio. O dever de ajudar as crias a nascer e a percorrer longas distâncias. A preocupação de renovar regularmente as camas dos animais. $\mathrm{O}$ tratamento higiénico, os cuidados e afetos, prestados quotidianamente aos animais de locomoção. A conservação dos exemplares envelhecidos ou diminuídos, já sem interesse económico. A morte piedosa de animais gravemente doentes ou aleijados por imperativo de pôr fim ao seu sofrimento visível e insuportável - constituem exemplos concretos, entre muitos outros, dessa ética imanente. Afetividade e memória comunitária: na verdade, não são apenas razões estritas de ordem económica ou de pragmatismo funcional que explicam a construção secular dessas práticas. Os animais possuem códigos de comunicação e resposta afetiva que interagem com o tratamento humano. E esse capital afetivo entrelaçou-se nas memórias e atitudes da consciência coletiva das comunidades rurais, transmitidas de geração em geração.

Transcendência ética: o seu imaginário reconhece a transcendência ética destes factos e não apenas em função do imperativo religioso, por isso o antigo inimigo tira o chapéu na passagem do funeral e o camponês endurecido enterra o seu cão sem conseguir esconder os sentimentos de desgosto.

Ética comparada, amoralismo e indiferentismo: a mecanização do quotidiano anónimo das cidades e das suas práticas de consumo, a urbanização maciça do espaço rural, traduziram-se não apenas na redução do património biogenético dos campos mas também da sua herança ética secular, favorecendo o amoralismo e o indiferentismo deste fim de século.

\section{A paisagem}

Para conocer una patria, un pueblo, no basta conocer su alma - lo que llamamos su alma - lo que dicen y hacen sus hombres; es menester también conocer su cuerpo, su suelo, su tierra, Yo os aseguro que pocos países habrá en Europa en que se pueda gozar de una variedad de paisajes que en España. ${ }^{16}$

${ }^{16}$ Citado em Escritos de Unamuno sobre Portugal, Estúdio, Compilación y Notas de 


\section{A elaboração do conceito de paisagem}

Coube à Geração de 70 e ao seu principal teórico, o esforço primordial para pensar e conceptualizar a paisagem: Moniz Barreto apreendeu, na sua função de crítico, o conceito sistémico da paisagem e a necessidade de a interpretar à luz de uma nova cosmovisão assente numa pluralidade científica e estética. No prefácio ao Portugal Contemporâneo, de Oliveira Martins, elabora esse conceito de uma forma sintética e clara: "Uma paisagem é um conjunto de elementos materiais coordenados de um certo modo no espaço e refletidos de um certo modo no espírito." 17 Distinguindo depois dois tipos de paisagens, a que chama descritiva e expressiva, que documenta em seguida na obra de Oliveira Martins, apresentando extratos diferentes onde elas se manifestam ou combinam, de tal modo que se umas são a "transcrição de emoções" outras traduzem "a explicação de um mecanismo". Porque, como afirma Moniz Barreto,

a palavra, pela sua origem provável e pela sua ligação com a paisagem, é uma expressão natural dos movimentos da alma, que a obra literária tem antes um alcance moral do que um valor plástico e ver-se-á ...que o Sr. Oliveira Martins procedia na composição das suas paisagens, não como um pintor mas como um poeta. Como um poeta e como um geógrafo. Não só as suas paisagens são sentidas, mas ainda pensadas. Elas são para ele, não só fontes de emoção, mas resultados de forças, constituídas em sistemas naturais pela comunidade das causas que a determinam, e pela identidade de efeitos que provocam nos espíritos sobre que atuam. ${ }^{18}$

Orlando Ribeiro, na sua comunicação Geografia e Reflexão Filosófi$c a$, apoiando-se na Geographia de Estrabão, sublinha a sua polimatia (pluri e interdisciplinaridade):

Pensamos que é uma preocupação do filósofo, se de alguma outra ciência o foi, a Geografia, que agora nos propomos estudar...A polimatia (pluridisciplinaridade) que, só por si, pode conduzir ao termo este trabalho, não existe em nenhum homem que não considere simultaneamente o divino e o humano, a cujo conhecimento chamam a Filosofia. ${ }^{19}$

Ángel Marcos de Díos, p. 4, de Obras Completas de Miguel Unamuno, 9 vols, publicados, Madrid, Escelicer, 1966-1971, vol. I., p. 282.

17 Martins, Oliveira. Portugal Contemporâneo. A Geração de 70, Quinto Volume. Lisboa: Círculo de Leitores. Prefácio de Moniz Barreto, 1987, p. 28.

18 Ibidem, p. 31.

19 Orlando Ribeiro, Geographia de Estrabão, Geografia e Reflexão Filosófica, in Memória da Academia das Ciências de Lisboa, Classe das Ciências, Tomo XXI, Lisboa, 1980, p. 188. 
Neste contexto, entende o divino como instrumento e o humano enquanto objeto da sua Filosofia. Neste mesmo texto, cita Ratzel e o seu "mestre" Silva Telles, que no fim do século XIX comungavam da mesma visão profética que.. "quanto mais o homem se civiliza mais depende da natureza". ${ }^{20} \mathrm{O}$ que significa o reconhecimento premonitório da não-exterioridade do homem face à natureza, mas também do reforço da presença humana no seio dessa natureza, por força do impacto crescente das novas tecnologias. Prossegue Orlando Ribeiro:

a Geografia, é como uma ponte lançada entre a natureza e o passado (Ritter) e, enquanto corpo científico, uma ciência de observação seletiva e descrição significativa da paisagem, que, pela sua complexidade, não se pode reduzir a modelos matemáticos computorizados e cuja metodologia, indutiva e dedutiva, apenas nos permite «tocar a verdade» (Henri Baulig). Sem ignorar que, por trás das claridades que a razão faz resplandecer, permanece o mistério que o pensamento filosófico pretende penetrar de maneiras por vezes contraditórias. ${ }^{21}$

É este apenas tocar a verdade, estas marcas humanas na paisagem, esta parte do mistério eternamente procurado, de que fala Goethe (Conversações com Eckerman), evocado por Orlando Ribeiro: "e muitas coisas nunca conseguiremos aproximar-nos mais que um certo limite que a Natureza reserva sempre por detrás daquilo que nos é acessível, qualquer coisa de problemático"22.

Eis pois uma nova conceção da natureza que emerge contendo na sua essência a crítica à visão moderna da natureza, duas vezes milenar: nem exterioridade absoluta, nem legibilidade final, o mistério permanece e é a ciência moderna que o confirma. Aqui encontra o seu limite o campo científico, no seu esforço de compreensão do mundo e abre-se, não necessariamente o domínio do finalismo religioso, mas o campo da filosofia e das suas éticas.

\section{A ecologia da paisagem - património material}

Este conceito incorpora progressivamente uma dimensão científica plural: a Ecologia, enquanto ciência da relação dos seres com o meio biótico e abiótico; a Geografia e a História quando estudam a humanização dos grandes quadros naturais; a Biologia que revela a importância da

\footnotetext{
${ }^{20}$ Ibidem, p. 191.

21 Ibidem, pp. 200 e 201.

22 Ibidem, pp. 201 e 202.
} 
diversidade dos seres vivos; a Geologia que revela as condições paleo-ambientais geradoras dos ciclos de extinção e expansão da biodiversidade; a Matemática que fornece modelos de gestão do ambiente; a Física e a Química quando analisam a qualidade dos elementos naturais do ambiente e os fatores de poluição ou investigam os fenómenos de mudança climática... ao mesmo tempo que remete para a necessidade de avaliar o nosso modelo de crescimento nos planos da ética e da moral. A ecologia da paisagem comporta a sua dimensão Física-científica. A História Natural, servida pelas Ciências da Terra, pela Geologia e a Geomorfologia em particular, revela-nos a diversidade do património geológico e aos seus monumentos naturais. As Ciências da Vida informam-nos das dimensões e do valor da biodiversidade, sobretudo a Biologia e a Botânica, tal como sobre o valor dos novos biótopos resultado da humanização da paisagem. A História Social, nas suas valências arqueológicas, artísticas e etnográficas, permite-nos usufruir do património construído, das obras de arte e literatura, e dos objetos e peças etnográficas...

\section{Dimensão Metafísica da paisagem - património imaterial}

A Metafísica da paisagem é do domínio da "espiritualidade", da "alma" das coisas, das categorias e sentimento estéticos, da "beleza" e do "belo" ou do "sublime", do "épico e do trágico", do "maravilhoso" e do "misterioso", do "monumental", da Literatura e da Arte, do imaginário individual e coletivo. O sentimento estético e o gosto, associados não apenas à criação artística mas também à relação com a natureza de que faz parte, parecem ser atributos exclusivos dos descendentes do homem sapiens sapiens. A arte rupestre emerge e permanece desde há mais de 40.000 anos nos santuários aborígenes australianos.

A paisagem "selvagem" é, afinal, paisagem humanizada: os Covões do Vale Glaciar de Loriga ou da Lagoa Comprida, na Serra da Estrela, recebem em cada Verão os pastores e rebanhos em transumância, renovando os cervunais e semeando com os seus corpos a biodiversidade nos recantos mais remotos da Serra.

O sortilégio da história natural e a geomorfologia desenharam as dobras misteriosas dos filões de xisto e a rotura do filão quartzítico pelo rio Ocreza. Novos biótopos surgiram com o prado de montanha, adubado, tal como as videiras do Douro, "a rabo de ovelha". A domesticação do zambujeiro gerou a metamorfose da oliveira. E à condição de zambujeiro regressam os braços das milenares oliveiras que o camponês deixou de podar e varejar. Pastores transumantes, nas canadas, veredas e cordeles que demandavam o Douro e a Serra de Montemuro, apuraram a resistência da ovelha bordaleira e cobriram-na de lã fina e preciosas carnes. As 
águias limparam as montanhas dos miasmas dos animais doentes que não resistiam à transumância. Assim nasceu e evoluiu a Paisagem Cultural, misturando o equilíbrio e a harmonia dinâmicos, com o caos e imprevisibilidade da tectónica da Terra.

É precisamente no cruzamento dos caminhos da estética (e da arte) e da ciência, que a paisagem cultural tem a sua origem. $\mathrm{O}$ misterioso e o sublime, expostos e revelados pela geodiversidade na paisagem do Cântaro Magro e do Vale Glaciar de Loriga. A épica e a monumentalidade da paisagem, construídas em socalcos pelos camponeses, pastores e silvicultores de Loriga. O belo e o trágico explicados pela história e a etnografia nas casas silenciosas de Casal do Rei e na sua intacta mas, agora inútil, ponte de xisto. A dialética trágica do ermamento do mundo rural, solares e arquitetura vernácula arruinados versus a sobre urbanização das cidades regionais, mas ainda o belo de Marialva, a aldeia medieval de granito e o seu caos de blocos...

O falar dos homens e mulheres das Terras do Demo, que Aquilino utilizou como matéria-prima da sua escrita, com a liberdade poética que a criação literária permite, tornou-se inteligível com a linguística e a gramática portuguesa. E revelou-nos outras dimensões sensoriais e histórico-culturais. De facto, criando uma nova escrita, não com a subversão da norma contemporânea, mas pela reestruturação do seu corpo morfológico com um vocabulário vernáculo, conduziu-nos às primitivas representações da relação entre o ser humano e a natureza.

Manhã cedo, rompe a cantata, nas árvores de fruto e pela mata.

- Sol, Sol! - trauteiam os pardais, tordas, melros e verdiais.

- Sol, Sol! - pede o tuinho na balsa

e o auricu que apagou o candil na salsa. ${ }^{23}$

Biodiversidade complexa, paisagem complexa, com a sua musicalidade, onde a crítica literária urbanizada apenas reconhecia "regionalismo".

${ }^{23}$ Ribeiro, Aquilino. O Livro de Marianinha. Lisboa: Livraria Bertrand. 1962. "Peto verdial", ou cavalinho, palavra de origem vernácula, provavelmente pré-latina, onomatopeica, “...o seu canto - um forte grito matraqueado - lembra o relinchar de um cavalo”. (J.I. Louro). 


\section{Metafísica da paisagem: Representação pela Arte e pela Literatura. Imaginário erudito e popular}

A crítica de arte internacional, de que é figura destacada Carlo Argan, ao analisar as relações entre forma e signo, situa no final do período entre as duas guerras mundiais o abandono da representação em favor do signo, deixando claro que esta questão não pode ser confundida com a distinção entre figurativo e não figurativo. Como exemplo, refere o figurativo, não representativo da realidade mas do fantástico, em Chagall, ou as formas biomórficas, não figurativas mas representativas da procura de valores universais, em Miró. ${ }^{24} \mathrm{~A}$ visão crítica da Pós-Modernidade é o fim da mimesis e o golpe de misericórdia na dessacralização da arte, já não só no aspeto religioso mas no próprio plano do racionalismo, que anunciou, três séculos antes, a modernidade da cultura ocidental. Este tempo é completamente diferente do passado.

A Arte como mimesis, de raiz aristotélica ou a arte como representação do Belo (clássico e renascentista) - resplendor do Divino (medieval) ou de Pã, reminiscência platónica ou hegeliana, cedeu o seu lugar a um universo de expressões artísticas que se expandiram em todos os sentidos, para depois se contraírem, misturarem, explodirem, recriando o caos cosmológico, de incontáveis idioletos, tendo como eixo criador comum a autonomia da obra de arte e referência principal a própria atividade dos artistas, estrelas singulares ou magníficos cometas arrastando atrás de si um rasto deslumbrante de novos sinais. Mas com esta mudança desfez-se igualmente o paralelo que o século XIX e o naturalismo tinham estabelecido entre a representação artística e o "olhar" da paisagem. A paisagem como tema quase desapareceu da criação artística, enquanto a arte, sobretudo a pintura mural mas também a escultura de grandes dimensões, regressava às ruas e praças das cidades. "As Promessas", com a procissão que Malhoa transforma em matéria plástica, representa uma das últimas obras dessa tradição, ainda viva no Portugal dos anos 20 do séc. XX, revisitada mais tarde pelo neo-realismo dos anos 40. Mas esta imagem artística afasta-se do naturalismo e surge já penetrada por uma iconografia simbólica. Na composição proto-expressionista das "Promessas", ainda no contexto das referências tradicionais da pintura naturalista, as figuras populares do primeiro plano e o vermelho sangrento dos andores, pendões, telhados, opas e blusas, emergem dissonantemente como autênticos signos de sofrimento da condição humana. Conservando a dominân-

${ }^{24}$ Argan, Giulio Carlo. Arte e Crítica de Arte. Lisboa: Editorial Estampa, Lda., 1995. pp. 108,109 e 110 . 
cia de cor garrida e berrante, esta é aplicada como metáfora do drama e sofrimento a que a emoção religiosa cruamente se expõe.

Os valores da linguagem plástica penetram o nosso modo de "olhar a paisagem". A forma simbólica como determinação de valores, planos de utilização e de configuração do status social; a função simbólica, em relação com a sociedade ou mântica (de comunicação com os deuses, ou expressão trágica da sua morte); os significados simbólicos ligados às crenças ou à indefinível descrença, deste fim de milénio, na providência, na finalidade da história ou no destino do homem. Na obra de Pomar "O Gadanheiro" a imagem, fotográfica-hiper realista-expressionista do segador, numa paisagem de estepe cerealífera, agiganta-se em ondas de cor e movimento que prenunciam a sua própria emancipação social.

Sigamos então a perspetiva heideggeriana, como referência da Modernidade e do novo modo de olhar as coisas e as coisas da arte, da origem da obra até ao emergir da arte moderna:

A Arte é Coisa e mais Outro, alegoria e símbolo. A interpretação das coisas pela matéria-forma vem da Idade Média (fundada na Fé) à Idade Moderna (o transcendental Kantiano). ${ }^{25}$

E acompanhemos a sua leitura da obra do quadro de Van Gogh que representa as botas do camponês após o dia de trabalho, ligando-a com o conjunto de outras obras suas que têm a paisagem como fundo, tal é "O Semeador", "Camponeses e Camponesas" e o quadro "Os comedores de Batatas," a nesga da paisagem urbana, como um rasgão que abre o mundo-paisagem dos bairros operários: o que importa é que no seu aspeto gasto (das botas do camponês) fita-nos a dificuldade e o cansaço dos seus passos de trabalhador, no couro está a humidade e a fertilidade do solo, sob as solas insinua-se a solidão noturna do dia que cai; por este apetrecho passa a angústia da fome eminente e a silenciosa alegria de vencer a miséria...

Regressamos a Malhoa e à sua derradeira obra, o Retábulo da Igreja de Chão do Couce (1931): o rosto da camponesa quebra o cânone da figura transreal de Nossa Senhora, a luz do manto desmaterializa a forma e transforma-se em símbolo, "o manto tecido de luz" e o olhar levantado numa censura aos céus, como o Cristo-Homem no momento terrível da agonia ("Pai, porque me abandonaste?", aqui transformado no queixume, "Meu Deus, como pode existir tanto sofrimento, miséria e abandono neste povo que se ajoelha aos teus pés em busca de alívio?"), o braço aberto num protesto, o abraço protetor sobre a doença, as enfermidades e o abandono das crianças, mães demasiado jovens, velhos, todos estes sig-

${ }^{25}$ Heidegger, Martin. A Origem da Obra de Arte. Lisboa: Edições 70, 1999. 
nos, à paisagem humanizada nos conduzem. Evoquemos, finalmente, a representação da paisagem pela Arte e pela Literatura com a mesma "Nave de Pedra" (a aldeia de Monsanto e o seu enquadramento paisagístico) escrita e pintada (1940?) por Fernando Namora.

Expressionismo e valores plásticos da cor, humanização da arte a partir dos objetos e artefactos criados pelo homem, a recordar-nos que o homem é o grande presente-ausente na paisagem cultural, mesmo quando não o vemos ou representamos. A impossibilidade de separar o sujeito contemplador kantiano do objeto-paisagem contemplado.

\section{Terra Ignota. Transcendência da paisagem}

Como Humboldt, Goethe ou Einstein creio firmemente na «harmonia interna do nosso mundo», lógico como condição da inteligibilidade; com Jacques Monod «no postulado de base do método científico: a saber que a natureza é objetiva e não projetiva». Sem ignorar que, por trás das claridades que a razão faz resplandecer, permanece o mistério que o pensamento filosófico pretende penetrar de maneiras por vezes contraditórias. $^{26}$

Enfim, não nos basta falar simplesmente de ecologia e metafísica da paisagem, porque se torna necessária a vivência e a intervenção do sujeito (individual ou coletivo, comunidade etnográfica ou artista singular) para ler, interpretar e recriar o que nestes conceitos se expressa nos domínios das diversas ciências e das denominadas Humanidades. E porque a própria paisagem, na sua dinâmica evolutiva e relação com o Homem, representa mais do que a soma da natureza e das marcas da sua humanização cultural, possui uma terceira dimensão onde se interligam a ecologia e a metafísica, elemento categorial que resulta da criação artística e das outras obras do espírito e, noutro plano, da afetividade do indivíduo, da comunidade e mesmo da nação; e se expressa através da criação de objetos culturais, eruditos e populares e da própria memória e evolução do espírito humano. Essa vivência múltipla é irredutível a uma categoria, pelo que, à falta de melhor, lhe chamaremos "Terra ignota, transcendência da paisagem". E este é o domínio da Filosofia.

Reafirmamos: a conceção metafísica não se opõe à realidade física da natureza, mas transcende-a. É transcendente por oposição a empírico o que é condição apriorística e não um dado da experiência. Contudo, falamos de uma perceção transcendental como aquela que se funda numa

${ }^{26}$ O. Ribeiro, Geographia de Estrabão, Geografia e Reflexão Filosófica, in Memória da Academia das Ciências de Lisboa, Classe das Ciências, Tomo XXI, Lisboa, 1980. 
relação necessária com a experiência. Tal sucede porque transcendente e transcendental não são da mesma natureza. Um princípio é transcendente quando suprime os limites do seu uso empírico. Utilizamos o conceito de transcendental na aceção kantiana, aplicado a um conhecimento da natureza. Mas também no mesmo sentido em que Hegel afirmava a identidade do sujeito e do objeto, ou seja, da possibilidade de um "conhecimento absoluto", atingível pelo acumular quantitativo de conhecimentos científicos, leituras e interpretações artísticas, religiosas ou psicológicas, até à sua transformação, numa etapa superior, da quantidade em qualidade, o que não significa dominação e inteligibilidade completas e definitivas. Assim sendo, no quadro da Filosofia da Natureza e do Ambiente, a ecologia da paisagem conduz-nos à sua interpretação e leitura pela via das ciências.

A metafísica da paisagem parte desta epistemologia científica e articula-a com uma ontologia estética e cultural plasmadas na história, na vivência contemporânea e na prospectiva de futuro dos seus povoadores.

\section{A Conferência de Estocolmo, 1972 e a CNA, 1971.}

A sociedade contemporânea reconheceu pela primeira a relevância universal da reflexão da Filosofia Ambiental e das suas éticas práticas ao convocar a United Nations Conference on the Human Environment, Stockholm, June 1972 e ao aprovar o seu relatório, elaborado por Dubos e Ward e os seus "Principles". Para preparar a participação nacional na Conferência é criada em Portugal no ano de 1971, a Comissão Nacional do Ambiente. Dessa conferência emerge, como imperativos éticos, the principle of common house ... the man has two homelands, his own and the planet Earth; the principle of planetary Community e planetary solidarity, e ainda, the principle of planetary defense of life and their biodiversity, fundadores de uma Nova Ordem (Ética) universal.

A conferência, ao estabelecer o princípio de que "...o homem tem duas pátrias, a sua e o planeta Terra", transfere para o plano político os princípios da crítica ao antropocentrismo e etnocentrismo ${ }^{27}$. Determina o seu objetivo como o de definir os problemas ambientais e os modelos de comportamento que assegurem o desenvolvimento das civilizações, consignando nos seus Principles as primeiras normas da ética política ambiental.

27 Action Plan for the Human Environment. B.5. Development and Environment. United Nations Conference on the Human Environment A/CONF.48/14/Rev.1-June 1972 Stockholm, Sweden. 
The Principle 1. Man has the fundamental right to freedom, equality and adequate conditions of life, in an environment of a quality that permits a life of dignity and well-being, and he bears a solemn responsibility to protect and improve the environment for present and future generations. In this respect, policies promoting or perpetuating apartheid, racial segregation, discrimination, colonial and other forms of oppression and foreign domination stand condemned and must be eliminated.

O relatório incorpora o conceito ampliado de comunidade, no sentido leopoldiano, e organiza-se em cinco grandes áreas: A Unidade do Planeta. As Unidades da Ciência. Os Problemas da Tecnologia. Os Países em Vias de Desenvolvimento. Uma Ordem Planetária.

Na primeira, procede-se a uma análise da herança civilizacional da Humanidade até ao atual modelo de ordenamento social. O homem é recolocado no seu contexto da relação natural com todos os seres e a condição humana encarada na sua totalidade física, psíquica e social, reconhecendo-lhe a necessidade de usufruir do conjunto dos benefícios da civilização, do bem-estar à saúde e instrução, e a viver num mundo de paz e de equilíbrio com a sua e a restante natureza. Logo no início se estabelece uma demarcação com o etnocentrismo, ao valorizar o desenvolvimento tecnológico e produtivo da China e da Índia do século XIV, em comparação com a Europa, assinalando o século XVII como o momento histórico de aceleração do desenvolvimento da sociedade, com base no seu património da(s) cultura(s) clássica e histórica, a partir do crescimento ininterrupto de fatores como o crescimento demográfico, o aumento do consumo de energia, de alimentos e minerais e a emigração do campo para a cidade, que viriam a atingir, já no século XIX, de viragem histórica, uma progressão exponencial. Sob esta base nasce o desequilíbrio crescente entre a biosfera e a tecnosfera, com o homem no centro do conflito.

Os autores, no plano da Filosofia, valorizam sobretudo as contribuições de Francis Bacon e de René Descartes, respetivamente, para o conhecimento útil e a elaboração de uma metodologia científica. Apontam, sinteticamente, os caminhos do racionalismo mecanicista e moderno na descoberta da natureza da energia e das forças universais, para chegar às descobertas sobre os elementos e a sua tabela e às ondas eletromagnéticas. Enfim, enfatizam a importância destas duas descobertas fundamentais - a tábua de elementos e o espectro eletromagnético - para a compreensão da composição atómica da matéria e da sua prometeica utilização tecnológica. Questionam então o processo contemporâneo de desenvolvimento da ciência, no sentido de uma "dissociação e especialização crescentes", saúdam a procura de novas sínteses e alertam para a necessi- 
dade de as encontrar no contexto do estudo pluridisciplinar dos sistemas naturais e interrogam-se sobre o valor ético dos níveis brutais de produção, consumo e violência, a que chegou a nossa sociedade, regressando a Bacon, para quem os novos deuses já eram... "os ídolos do mercado e os ídolos da tribo". Avaliam o preço da prosperidade em termos ambientais, e analisam as características atuais da mundialização do mercado e da sua relação com a soberania e o papel do Estado, lamentando que tenham passado dois séculos até se começar a definir um novo "contrato social" regulador do funcionamento cego da economia, cuja generalização e reforma em favor de um novo equilíbrio advogam à escala mundial, seja na forma socialista de planeamento económico, seja através de sistemas mistos e da participação cívica e política.

The Principle 24: International matters concerning the protection and improvement of the environment should be handled in a cooperative spirit by all countries, big and small, on an equal footing. Cooperation through multilateral or bilateral arrangements or other appropriate means is essential to effectively control, prevent, reduce and eliminate adverse environmental effects resulting from activities conducted in all spheres; in such a way that due account is taken of the sovereignty and interests of all States.

Estas ideias gerais serão desenvolvidas nos capítulos seguintes e vão conduzir às propostas finais, enquadradas na solução política das "divisões trágicas e crescentes entre os povos ricos do «Norte» e os povos miseráveis do «Sul»". Cuja origem situam nas transformações políticas ocorridas no século XIX, com a consolidação das nacionalidades, a expansão dos impérios e a partilha colonial do mundo. Propostas, enquadradas igualmente numa nova ética, imposta (também) pela ameaça de extinção da humanidade pela poluição do planeta e pela ameaça de guerra química ou nuclear...

Hoje, nós só podemos esperar sobreviver se conservarmos a nossa preciosa diversidade, e na condição de gerar uma lealdade fundamental face ao nosso planeta Terra, este planeta único, tão belo e tão vulnerável.

The Principle 3: The capacity of the earth to produce vital renewable resources must be maintained and, wherever practicable, restored or improved.

Na segunda parte do Relatório, dedicada à elaboração de uma nova visão científica sobre a unidade, imprevisibilidade, continuidade e interdependência do cosmos (é neste sentido que se fala de equilíbrio dinâmico), introduz-se, no que respeita ao entendimento da realidade da matéria 
o conceito de «plasma», que permitiu entender a origem do Universo e os fatores que geraram na Terra as condições de transformação criadoras e conservadoras da vida: a água, que arrefeceu a temperatura do planeta e moldou a sua crusta, os compostos orgânicos de carbono, fontes da vida, a atmosfera de oxigénio e ozono, protetores da vida, a fotossíntese, base dos ciclos do carbono e do oxigénio, a criação da biosfera e a explosão da vida no Câmbrico, o complexo, vulnerável e imprevisível processo de adaptação e seleção natural, que gerou sempre, até ao nosso tempo, uma crescente biodiversidade e diversidade natural, em instável equilíbrio. $\mathrm{O}$ princípio de defesa da Vida Planetária e da sua biodiversidade encontra aqui a sua fundamentação científica.

Na terceira parte é analisada a descontinuidade do desenvolvimento, os problemas da expansão do consumo, concentração da produção e troca, esgotamento dos recursos, que acentuam os problemas de poluição e as desigualdades sociais à escala planetária. Aqui se introduzem novas perspetivas de abordar os custos sociais da economia, considerando os custos ambientais, na época quase ignorados e sistematicamente socializados, desde a poluição à destruição dos solos, enquanto suporte da vida e da paisagem cultural, a crise do urbanismo, a destruição dos habitats do mundo rural, a preservação de regiões selvagens, o reequilibrar dos recursos em função das reais necessidades da humanidade como um todo, a conservação e gestão limpa dos recursos energéticos, a promoção da qualidade de vida ambiental e de uma política integrada de justiça social e de solidariedade internacional.

A quarta parte é dedicada a analisar a situação dos chamados países em vias de desenvolvimento, cujo conceito engloba realidades ambientais e culturais bem diversas, desde os países de antiquíssimas civilizações aos que apenas recentemente adquiriram um estatuto independente. $\mathrm{O}$ Relatório incide sobre os avanços provocados pela "Revolução Verde", que ocorre nos anos 60, as potencialidades de emprego e produção mas também avalia as suas contradições, sobretudo em consequência do uso abundante de agro-químicos, da expansão urbana e explosão demográfica nestes países, os novos problemas ecológicos nascido de uma crescente industrialização, e a criação de condições políticas e sociais favoráveis à repartição dos benefícios.

O último capítulo equaciona a criação de uma nova ordem internacional, através de uma justa e correta gestão internacional da biosfera, que controle e corrija as disfunções ambientais, na atmosfera, climas e oceanos, propõe a reforma da tecnosfera - sistema mundial de inovação tecnológica, investimento e trocas comerciais, apontando as soluções pacíficas e negociais como condição para o estabelecimento de uma estratégia de sobrevivência da Humanidade e da Terra, sua Casa Comum. 
Um elemento importante seria a regulação pacífica dos conflitos, através de procedimentos legais de arbitragem política e numa base internacional. Um outro seria a transferência de recursos dos ricos para os pobres graças a uma progressiva repartição mundial: é o mesmo sistema cuja fórmula que foi fixada para a ajuda aos países do terceiro mundo, $1 \%$ do produto nacional bruto dos países ricos, constitui o primeiro esboço. Quanto a uma planificação mundial da higiene e da educação, de investimentos mundiais numa agricultura de progresso, uma estratégia mundial para criar melhores cidades e uma ação mundial para monitorar a poluição e melhorar o ambiente, tudo isto não seria mais do que extensões lógicas duma cooperação intergovernamental limitada, tal como já hoje se impõe em função das necessidades e dos interesses funcionais recíprocos. [...] Mas atualmente, a ideia de estabelecer estas estratégias através de uma autoridade, uma ação e recursos adequados parece ainda estranha, visionária e utópica, simplesmente porque as instituições mundiais não se apoiam em nenhum sentido real de comunidade planetária nem em nenhum compromisso a esse respeito.

A perspetiva filosófica de crítica ao etnocentrismo conduz ao imperativo ético da eliminação das armas de destruição massiva - nucleares, químicas e biológicas, e à defesa da paz perpétua.

The Principle 26: Man and his environment must be spared from the effects of nuclear weapons and all other means of mass destruction. States must strive to reach prompt agreement in the relevant international organs on the elimination and complete destruction of such weapons.

A sua postura filosófica, acerca da condição humana, é claramente inspirada nas conceções de Konrad Lorenz, ao invocar o princípio de lealdade com a Mãe-Terra:

Porque é de lealdade que se trata, é a lealdade a chave da situação. Segundo muitos psicólogos modernos, o homem não é um matador em função de um imperativo biológico mas pelo contrário porque ele é capaz de uma profunda lealdade e ela é mal utilizada. O que ele hesitaria em fazer devido à sua própria natureza, fá-lo-á em nome de um ideal maior que ele próprio... Ora, nos dois planos, os novos imperativos da ecologia podem fornecer ao homem uma nova perspetiva, permitindo-lhe compreender onde reside em último recurso a sua verdadeira segurança, a sua dignidade e a sua verdadeira identidade. 


\section{Da complexidade da Paisagem - valor acrescentado da paisagem cultural, valor de uso, valor de troca e valor cultural}

Recorramos de novo a Catherine Larrère, para explicar o nascimento do gosto contemporâneo pela natureza, no caso, nos EUA:

Bien que John Muir ait affirmé la valeur intrinsèque de la nature, ait appelé au respect des droits de la création tout entière, dans la préservation de la wilderness on cherche d'abord la conservation de curiosités naturelles, d'un patrimoine artistique comparable à celui des musées européens, le maintien de terrains d'aventure où mettre à l'épreuve des qualités humaines de résistance et d'énergie. Que l'on y voit un lieu sacré, reflet de la volonté divine, ou le miroir de la mentalité démocratique et communautaire américaine, c'est un symbole que l'on protège dans la nature... C'est cette rencontre entre le sentiment populaire et national de la nature, et la précision et la rigueur scientifiques, qui peut expliquer que les États-Unis ont été un point central du développement de la réflexion morale sur la nature provoquée par la crise environnementale. ${ }^{28}$

Mas o reconhecimento do valor económico do uso da biodiversidade, e mesmo dos valores estéticos da paisagem, pode ser ainda uma forma de recusar os valores da Ética da Terra e da Ética da Vida. Conduz geralmente a confinar a conservação da natureza aos parques e reservas, às espécies potencialmente úteis ao ser humano e à ação do estado, deixando inteira liberdade à iniciativa privada na maior parte do território continental e marítimo dos seus países. ${ }^{29}$ Tal não significa que não se reconheça a importância política do reconhecimento expresso no Direito do conceito prático de "Áreas protegidas", que assumem um grau de proteção degressivo conforme a sua Classificação: 1.1 Parque nacional; 1.2 Parque natural; 1.3 Reserva natural; 1.4 Monumento natural; 1.5 Paisagem protegida; 1.6 Sítio de interesse biológico.

O conceito de monumento natural, inicialmente associado aos indivíduos biológicos, como a azinheira centenária e a oliveira milenar, ampliou-se aos Geomonumentos, classificados e tipificados pelo geólogo Galopim de Carvalho como afloramento, sítio e paisagem. Materialização conceptual do conceito ambiental de "comunidade" e alargamento das categorias éticas, e da ética prática, ao ambiente abiótico. Processo que

${ }^{28}$ Larrère, Catherine. Éthiques de l'environnement. Multitudes, Vol. 2006/1 (24), pp. 75-84.

29 "The land-relation is still strictly economic, entailing privileges but not obligations.", Aldo Leopold, A Sand Count Almanac, p. 238. 
origina igualmente a criação da Rede Natura 2000, a Diretiva habitats e a definição legal de Zonas de proteção Especial, Diretiva Aves.

A paisagem não é um livro aberto, inteligível empiricamente. $\mathrm{O}$ seu uso e a sua legibilidade, que lhe conferem valor económico e cultural, é uma metamorfose que, no plano da economia gera valor, e é também um processo de literacia, mediado pela construção da linguagem de comunicação e representação artística, questões pouco estudadas; o resultado deste processo altera a forma e a essência dos conceitos tradicionais de paisagem como recurso económico e produto cultural (material e imaterial), e coloca a questão da ética. Exemplifiquemos: o esforço monumental de armação do Terreno só na povoação de Loriga - cerca de $30.000 \mathrm{~m}$ de muros de suporte, com alturas médias entre 2 e $4 \mathrm{~m}$, atingindo por vezes mais de 6 metros, profundos arroteamentos e movimentação de terras, representa mais de 20 milhões de euros a preços atuais. A paisagem camponesa, na sua estética e valor moral, encerra também valores económicos mensuráveis pelo mercado que são quantificáveis e significativos. $\mathrm{O}$ gosto moderno é determinado pelos valores éticos, estéticos e do património cultural e natural, e, em última instância pela escolha de uma ideologia política. Tal explica que o labor filosófico de Heidegger sobre a estética e a arte possa coexistir no ser humano único e singular com a simpatia pela política nazi, ou pela política franquista, em Ortega y Gasset, na sua crítica à desumanização da arte.

A paisagem cultural, rural e urbana, começou a ser desfrutada como um produto turístico graças ao surgimento e difusão do paisagismo, na sua dimensão científica e estética, disseminando o gosto pela sua procura em todas as classes sociais, mas também em paralelo com o reconhecimento, pelas democracias liberais e socialistas, do direito ao lazer. Mas a questão do gosto está ligada intrinsecamente ao problema dos valores e portanto, à ética e à moral social, nomeadamente á ética política. Por isso encerramos este capítulo com o pensamento dos paisagistas:

É tempo de afirmar que se a cidade é indispensável à organização da sociedade e ao progresso da humanidade, se a indústria muito tem contribuído para facilitar a vida e lhe dar conforto... é da paisagem rural que depende a sobrevivência da humanidade, porque é ela com o mar, a única fonte de alimentos, a única fonte de água potável, e o último suporte de atividade biológica autónoma e equilibrada, indispensável à continuação da vida na terra. Por isso a atividade da Sociedade Rural é a única que continua a ser obrigatória, sendo todas as outras facultativas, quer a sociedade urbana-industrial se aperceba ou não desse facto. ${ }^{30}$

${ }^{30}$ Retirado do seu discurso durante a Conferência Mundial da Associação de 


\section{Categorias para-estéticas}

Podemos referenciar na paisagem da Serra da Estrela um conjunto de categorias que denominamos de para-estéticas, com um valor moral intrínseco: "O único", a sua Torre, cume panorâmico da Serra, coroa da neve, e configurar esse conceito como suscetível de expressar os atributos paisagísticos exclusivos de um sítio. "O singular", a Cabeça da Velha, formas antropomórficas do granito produto da sua erosão, definindo agora o conceito como atributos bastante comuns mas com forma identitária de um objeto paisagístico. "O autêntico", como o dólmen de Cortiçô, símbolo do esforço heróico dos primeiros agricultores e pastores, com os atributos conceptuais da conservação dos objetos e contextos paisagísticos originais, tais são os seus esteios de granito de vários tipos, de grão fino, mas também porfiróide, que, por não se encontrar nas redondezas, testemunha por si só o esforço épico dos seus construtores; local mágico, que parece orientado para o ciclo diurno do sol e representar simbolicamente a morte e a vida nos solstícios de Inverno e de Verão. "O genuíno e o raro", objetos e detalhes da paisagem humanizada, que no seu processo de evolução tendem para o desaparecimento ou corrupção, aqui expresso pela figura e obra de Mateus Miragaia, o último ferreiro do Jarmelo, fabricante das tesouras de tosquia da lã da Estrela, a sua oficina e as marcas do seu trabalho em toda a paisagem rural da aldeia do Jarmelo. E diferenciá-las das Categorias para-estéticas paisagistas (sistémicas).

Enunciemos algumas dessas Categorias para-estéticas sistémicas: "O Mosaico agro-silvo-pastoril", que constitui uma visão da paisagem, sistémica, pluri e interdisciplinar, material e espiritual, da paisagem humanizada (cultural) ou terroir, a floresta protegendo os cumes, os prados a meia encosta e no vale a horta e as terras de cultivo. "A Paisagem de Bocage", do francês bois, uma sebe contínua. Com o bosque no alto da encosta, sebes vivas e linhas de arvoredo ligando as mantas de terra e pastagem armadas sabiamente sob as linhas de declive, sem muros de suporte. "Prados de Lima", a água repartida finamente e como que limada em finos regatos nas veigas da ribeira, para que o pasto não seque no verão nem se queime pela geada no inverno; rega de lima mantendo o crescimento das pastagens e realizando a recarga alargada dos aquíferos. "Socalcos" monumentais, suportando o solo e recolhendo as escorrências pluviais. "O Carvalhal e a mata ripária", conservando a agricultura tradicional, local privilegiado de observação da avifauna. "Jardins aquáticos", cobrindo o leito dos rios e ribeiras. "Jardim de musgos": micro-flora e

Arquitetos Paisagistas, de que foi presidente eleito, em Tóquio, 1961, recolhida em testemunho indireto. 
micro-fauna, fungos de múltiplas cores e formas. A mais-valia paisagística e turística destas paisagens, as suas cores, musicalidade, salubridade, aromas, sabores...

Podemos identificar categorias estéticas e para-estéticas positivas, de par com as categorias estéticas negativas, num ciclo interminável de abandono e renascimento da paisagem cultural. O "feio", o feio dos fios elétricos cruzando o horizonte visual dos monumentos, das feridas abertas nos montes pelas pedreiras e o repugnante de um eucaliptal sem outras vidas. O "desinteressante" da monotonia verde monotonal de um pinhal. O "ofensivo", dos inertes e restos das construções marcando as valetas e as veredas, acentuando a dimensão moral do problema. "O repugnante" das lixeiras marcando a paisagem, do cheiro acre das celuloses em quilómetro de paisagens, das águas podres das ribeiras-esgoto, outra vez integrando o sentimento moral e estético.

Mas como avaliar esteticamente uma Aranha-lobo, no seu micro-habitat ou o labirinto das grutas, rios subterrâneos e cavernas cársicas, cobertas pelo verde viscoso dos líquenes microscópicos, ressumando ao cheiro acre da água salobra e povoadas de espessas nuvens de morcegos negros como o breu? O feio e o repugnante? Ou o belo e o sublime? A existência de uma dimensão categorial na paisagem, que se estabelece na vivência do indivíduo humano, que denominámos de transcendência da paisagem, conduz-nos, como na arte contemporânea ou pós-moderna ao reconhecimento da polissemia e plurissignificação da paisagem e dos seus elementos constitutivos, uma irredutível subjetividade que não se opõe nem à ciência nem ao gosto social e que constitui a base conceptual bem sucedida da criação prática dos Roteiros e Circuitos do Turismo Ambiental, Turismo Cultural e Turismo de Natureza. Mas que comporta uma consequência maior: a coexistência de distintas visões culturais sobre a paisagem é uma realidade absoluta e, portanto, a sua convergência no domínio da filosofia constitui uma necessidade incontornável para "ler e interpretar" os valores paisagísticos.

\section{Conclusão: Uma nova Ética Ambiental e os seus princípios}

Etnocentrismo é uma atitude emocionalmente condicionada que faz considerar e julgar outras sociedades pelos critérios originados pela própria cultura. É fácil ver que esta atitude leva ao desprezo e ao ódio de todas as espécies de vida que são diferentes daquela do observador. ${ }^{31}$

31 Jorge Dias, Estudos de Antropologia, Volume I, Uma introdução histórica etnografia portuguesa, p. 219, publicada em 1961. Lisboa: Imprensa Nacional-Casa da Moeda, 1990. 
Os conceitos fundamentais de "cultura", "natureza" e "paisagem" estão longe de ser objetos neutros do estudo científico. Eles são construções académicas que necessitam ser compreendidas no seu emergir ao longo de diferentes contextos históricos. Mas a evolução das ciências do ambiente ao conduzir a uma Filosofia nascida da observação e da leitura da paisagem e da síntese da Terra e do Homem que a habita e transforma (que designamos como «paisagem cultural»), mas ao mesmo tempo a ameaça degradar ou destruir, fundamenta a necessidade de uma ética ambiental

A moral é sempre uma expressão e representação determinada pelo contexto histórico e pela dominação social, o que lhe confere um carácter sectário. Necessitamos de uma teoria moral que possa ser universal, intemporal e capaz de orientar a conduta individual, a ciência e as ideologias políticas, mas que não considere o homem como o produto final da evolução da Vida. A biodiversidade da Vida na Terra representa apenas o cume atual da complexa evolução do Cosmos, mas nós não sabemos se a nossa espécie, nascida na Terra, representa o elo final da evolução cosmológica. Para procurar uma resposta a estas questões, nasceu uma nova perspetiva ética, uma teoria construída com os princípios meta-éticos aplicáveis a todas as atividades humanas.

Retomando as perguntas capitais que a obra de Espinosa colocou no advento da nossa modernidade, como pensar a explicação racional da existência do homem e do universo, como adequar o pensamento filosófico à razão de ser de tudo o que existe e como transformar a vida espiritual em plena compreensão e serena fruição da vida até ao seu limite? A Filosofia da Natureza e depois a Filosofia do Ambiente permitiram construir uma nova ontologia em crítica ao antropocentrismo, mas só a sua articulação numa nova epistemologia, fundada na crítica ao etnocentrismo, poderá conduzir a uma nova teoria ética, de valor universal e de conteúdos práticos aplicáveis a todos os domínios sociais.

\section{ABSTRACT}

Central conceptual terms, such as 'culture', 'environment', 'nature' and 'landscape', are far from being neutral scientific objects. They are academic constructions which need to be understood in their emergence across their historic contexts.

Morality is a cultural expression determined by social domination and historical context, which gives it a sectary character. We need a moral theory that can be universal, timeless and that is able to guide the individual conduct, science and political ideologies, without considering the man the zenith of Life. Life, with its biodiversity, is only the tip of a complex Cosmos evolution, but we don't know if our species, born on planet Earth, are the final link in the Cosmos 
evolution. To answer all these questions, a new ethical perspective was born, a theory built upon the principles of meta-ethics and applicable to all human activities.

Environmental ethics are supported by two principles - the critique against anthropocentrism and the critique against ethnocentrism, giving a universal answer to the macro moral problems of our era - environmental, social, economical and political crisis, war and weapons of mass destruction... And contributes towards rebuilding the human activities in all domains of individual and social life. 